\title{
LIPID PROFILE, FUNCTIONAL CAPACITY AND ANKLE- BRACHIAL INDEX IN ACTIVE OLDER ADULTS
}

\author{
PERFIL LIPIDICO, CAPACIDADEFUNCIONAL E ÍNDICE TORNOZELO-BRAQUIAL EM IDOSOS ATIVOS
}

Original Article

ARTIGO ORIGINAL

PERFIL LIPÍDICO, CAPACIDAD FUNCIONAL E ÍNDICETOBILLO-BRAQUIAL EN ADULTOS DE LA

Artículo Original

\section{TERCERAEDADACTIVOS}

Terezinha Sasaki Marques ${ }^{1}$ (Physical Education Professional)

Alessandro Domingues Heubel ${ }^{2}$ (Physiotherapist)

Camila Gimenes ${ }^{1}$

(Physiotherapist)

Eduardo Aguilar Arca'

(Physiotherapist)

Bruna Varanda Pessoa-Santos ${ }^{1}$

(Physiotherapist)

Bruno Martinelli ${ }^{1}$

(Physiotherapist)

Antonio Roberto Zamunér ${ }^{3}$

(Physiotherapist)

Silvia Regina Barrile ${ }^{4}$

(Physiotherapist)

1. Universidade do Sagrado Coração (USC), Center for Health Sciences, Physiotherapy Course, Bauru, SP, Brazil.

2 Universidade Federal de São Carlos (UFSCar), Physiotherapy Graduate Degree Program,

São Carlos, SP, Brazil.

3. Universidad Católica del Maule (UCM), Department of Kinesiology,

Talca, Maule, Chile.

4. Universidade de Cuiabá (UNIC), Department of Physiotherapy,

Cuiabá, MT, Brazil.

\section{Correspondence:}

Silvia Regina Barrile.

Av. Manoel José de Arruda, 3100 Jardim Europa, Cuiabá - MT, Brazil. 78065-700. srbarrile@gmail.com

\section{ABSTRACT}

Introduction: Regular physical activity prevents cardiovascular diseases (CVD) and atherosclerosis, in addition to improving lipid levels and functional capacity in older adults. Objective: To evaluate and compare the lipid levels, functional performance and ankle brachial index (ABI) of sedentary and active older adults. Methods: This was a comparative cross-sectional study with 84 elderly ( $\geq 60$ years) male and female subjects, divided into two groups: sedentary group $(S G, n=50)$ and active group ( $A G, n=34)$ according to the International Physical Activity Questionnaire (IPAQ). Anthropometric and hemodynamic assessments, ankle brachial index (ABI) calculations, and functionality tests (Short Physical Performance Battery - SPPB and 6-minute walking test - 6MWT) were performed. The Shapiro-Wilk normality test was also used, and we conducted the Student's-t and Mann-Whitney tests for the intergroup comparison. For the categorical data, we used Fisher's exact test $(p<0.05)$. Results: Higher values of high-density lipoprotein cholesterol (HDL-c) $(p=0.001)$ and lower triglycerides (TG) ( $p=0.007$ ) were found in AG compared to SG. In the ABl evaluation, AG presented better right ( $p=$ $0.012)$, left $(p=0.015)$ and end $(p=0.004) A B \mid$ rates when compared to $S G$. AG had better results in functional performance in the SPPB evaluation $(p=0.0007)$ and in the $6 \mathrm{MWT}$ with a greater distance covered $(p=0.0027)$. In the anthropometric measurements, AG had lower body mass index (BMI) (0.041) and a smaller abdominal circumference (WC) (0.029). In terms of the incidence of referred diseases, intergroup results were only different for hypertension (0.029), while AG had a lower incidence of hypertension. Conclusion: Active older adults had better lipid levels, higher ABI levels, better functional performance, lower body mass, a smaller abdominal circumference, and lower incidence of hypertension, in comparison to sedentary subjects. Level of evidence l; High quality prospective study.

Keywords: Aged; Sedentary lifestyle; Lipid A; Ankle brachial index.

\section{RESUMO}

Introdução: A prática de atividade física regular previne doenças cardiovasculares (DCV) e aterosclerose, além de melhorar o perfil lipídico e a capacidade funcional em idosos. Objetivo: Avaliar e comparar o perfil lipídico, desempenho funcional e índice tornozelo-braquial (ITB) de idosos sedentários e ativos. Métodos: Trata-se de um estudo comparativo e transversal com 84 idosos ( $\geq 60$ anos) de ambos os sexos, divididos em dois grupos: grupo sedentário ( $G S, n=50$ ) e grupo ativo (GA, $n=34$ ) segundo o Questionário Internacional de Atividade Física (IPAQ). Foram realizadas avaliações antropométricas, hemodinâmicas, índice tornozelo-braquial (ITB) e testes de funcionalidade (Short Physical Performance Battery - SPPB e teste de caminhada de 6 minutos - TC6). Além disso, foi utilizado o teste de normalidade Shapiro-Wilk e na comparação entre os grupos utilizou-se o teste t-Studente o teste Mann-Whitney. Já para os dados categóricos, utilizou-se o teste exato de Fisher $(p<0,05)$. Resultados: Foi verificado no GA valores maiores da lipoproteína de alta densidade (high-density lipoprotein cholesterol, $\operatorname{HDL}-c)(p=0,001)$ e menores de triglicerídeo (TG) ( $p=0,007)$ quando comparados ao GS. Na avaliação ITB, observou-se que o GA apresentou melhores índices de ITB direito $(p=0,012)$, esquerdo $(p=0,015)$ e final $(p=0,004)$ quando comparado ao GS. Houve melhores resultados do GA no desempenho funcional na avaliação SPPB ( $p=0,0007)$ e no TC6 com maior distância percorrida ( $p=0,0027)$. Nas medidas antropométricas, o GA apresentou menor índice de massa corporal (IMC) $(0,041)$ e circunferência abdominal (CA) $(0,029)$. Na incidência das doenças referidas, apenas a hipertensão apresentou resultados diferentes entre os grupos (0,029), sendo que o GA teve menor incidência de hipertensão. Conclusão: Os idosos ativos apresentaram melhor perfil lipídico, maiores níveis de ITB, melhor desempenho funcional, além de menor massa corpórea, menor circunferência abdominal e menor incidência de hipertensão em comparação aos sedentários. Nível de evidência l; Estudo prospectivo de alta qualidade.

Descritores: Idosos; Estilo de vida sedentário; Lipídeo A; Índice tornozelo-braço.

\section{RESUMEN}

Introducción: La práctica de actividad física regular previene enfermedades cardiovasculares (ECV) y aterosclerosis, además de mejorar el perfil lipídico y la capacidad funcional en adultos de la tercera edad. Objetivo: Evaluar y comparar el perfil lipídico, desempeño funcional e índice tobillo-braquial (ITB) en adultos de la tercera edad sedentarios y activos. Métodos: Se trata de un estudio comparativo y transversal, con 84 adultos de la tercera edad ( $\geq 60$ años) de 
ambos sexos, divididos en dos grupos: grupo sedentario $(G S, n=50)$ y grupo activo $(G A, n=34)$ según el Cuestionario Internacional de Actividad Física (IPAQ). Fueron realizadas evaluaciones antropométricas, hemodinámicas, índice tobillo-braquial (ITB) y tests de funcionalidad (Short Physical Performance Battery - SPPB y Test de Caminata de 6 minutos - TC6). Además, se utilizó el test de normalidad Shapiro-Wilk y en la comparación entre los grupos se usó el test t-Studenty el test Mann-Whitney. Ya para los datos categóricos se usó el test exacto de Fisher ( $p<0,05)$. Resultados: Se verificaron en el GA valores mayores de lipoproteina de alta densidad (high-density lipoprotein cholesterol, HDL-c) $(p=0,001)$ y menores de triglicéridos (TG) $(p=0,007)$ cuando comparados al GS. En la evaluación ITB, se observó que el GA mostró mejores índices de ITB derecho $(p=0,012)$, izquierdo $(p=0,015)$ y final $(p=0,004)$ cuando comparado al GS. Hubo mejores resultados del GA en el desempeño funcional en la evaluación SPPB $(p=0,0007)$ y en el TC6 con mayor distancia recorrida ( $p=0,0027)$. En las medidas antropométricas, el GA presentó menor índice de masa corporal (IMC) (0,041) y circunferencia abdominal (CA) (0.029). En la incidencia de las enfermedades referidas, sólo la hipertensión presentó resultados diferentes entre los grupos (0.029), siendo que el GA tuvo menor incidencia de hipertensión. Conclusión: Los adultos de la tercera edad activos presentaron mejor perfil lipídico, mayores niveles de ITB, mejor desempeño funcional, además de menor mas a corpórea, menor circunferencia abdominal y menor incidencia de hipertensión en comparación a los sedentarios. Nivel de evidencia l; Estudio prospectivo de alta calidad.

Descriptores: Anciano; Estilo de vida sedentario; Lípido A; Índice tobillo braquial.

\section{INTRODUCTION}

Currently, population aging is a global concern with regard to health and quality of life. Therefore, the interest of the scientific community in studying this population group increases. ${ }^{1}$

The changes resulting from aging, accompanied by sedentary lifestyles, are associated with reduced functional capacities in daily activities and impact the quality of life of the elderly. ${ }^{2,3}$ As a consequence, risk factors for cardiovascular diseases (CVD) such as dyslipidemia, obesity, arterial hypertension, and type 2 diabetes mellitus increase and may favor the development of atherosclerosis. ${ }^{4}$

Atherosclerosis is an inflammatory disease that mainly affects large and medium-caliber muscle and elastic arteries and can result in restricted blood flow to the heart, brain, or extremities. ${ }^{5}$

The restriction of blood flow to the lower limbs (LL), evaluated by the ankle-brachial index (ABI), is considered the gold standard and an important marker of atherosclerosis and predictor of cardiovascular risk., ${ }^{6,7}$

The practice of regular physical activity provides benefits such as improved health, minimizes degenerative effects caused by aging, and allows the elderly to maintain and increase the quality and perspective of life. Moreover, it is indicated as a factor of prevention of the development of atherosclerosis and for the improvement of lipid levels. ${ }^{2}$

With increasing population longevity, it becomes of fundamental importance for health professionals, communities, and governments to conduct further studies related to the elderly to identify changes in lipid levels, impairment of functional capacities, and risk factors for CVD, as well as identify the early diagnoses of inherent complications so that they can consider prevention and intervention programs and treatments.

Therefore, the objective of this study was to evaluate and compare the lipid profiles, functional performances, and ankle-brachial indices of sedentary and active elderly individuals.

\section{MATERIALS AND METHODS}

This was a cross-sectional study that included elderly individuals from a municipality in the interior of the state of São Paulo who were assisted in a Health Center from August to December 2015. This study was approved by the Ethics and Research Committee of the institution, opinion No. 1123873/2015, in accordance with Resolution CNS 466/12, according to the Helsinki declaration. All individuals signed an Informed Consent Form (ICF).

Volunteers were selected by convenience sampling as they attended the Basic Health Unit. Elderly individuals of both genders, aged $\geq 60$ years, who walked independently and who were willing to participate in the evaluations were included. We excluded those individuals whose ABls could not be measured (amputation, extensive ulcerations, fractures and severe pain in LLs), who had physical limitations to prevent them from performing functional tests, or who were unable to answer the questionnaires.

A total of 93 individuals participated in the study, 9 of whom were excluded. After exclusion, the sample analyzed was composed of 84 individuals who were divided into two groups: a sedentary group ( $S G, n=50$ ) and an active group ( $A G, n=34$ ), according to the level of physical activity assessed by the short version of the International Physical Activity Questionnaire (IPAQ) ${ }^{8}$ and interpreted according to the Advisory Committee on IPAQ which considers an individual active if they perform at least 30 minutes of moderate physical activity on five or more days per week and 20 minutes of vigorous physical activity on three or more days per week. ${ }^{9}$ Figure 1 shows the flowchart related to the screening, selection, and sample loss of the study.

All volunteers were interviewed to collect sociodemographic information and to evaluate the sample selection criteria. After inclusion in the study, the volunteers underwent blood biochemical tests in the morning, after a 12-hour fast, to evaluate their lipid profiles. Their total cholesterol (TC), triglyceride (TG), and high-density lipoprotein cholesterol (HDL-C) plasma levels were analyzed using an enzymatic-colorimetric method and their low-density lipoprotein cholesterol (LDL-c) was determined by the equation of Friedewald, Levy, and Fredrickson. ${ }^{10}$

The body mass index (BMI) utilized the measures of body mass $(\mathrm{kg})$ and height $(\mathrm{m})$ in the formula: $\mathrm{BMl}=$ body mass $/$ height ${ }^{2}\left(\mathrm{~kg} / \mathrm{m}^{2}\right) .{ }^{11}$ The measurement of abdominal circumference $(A C)$ was performed at the level of the umbilicus by means of a measuring tape using centimeters. ${ }^{12}$

Blood pressure (BP) was measured according to the 7th Brazilian Directive of Hypertension ${ }^{13}$ by means of a properly calibrated aneroid sphygmomanometer (Premium ${ }^{\oplus}$, Brazil). Heart rate (HR) was checked using an oximeter (Nonin ${ }^{\oplus}$, USA).

A portable vascular Doppler (MEDMEGA ${ }^{\circledR}$ DV610B: Franca/São Paulo) and an aneroid sphygmomanometer (Premium ${ }^{\circledast}$, Brazil) were used to measure the ABIs. Volunteers were instructed not to consume caffeine, alcohol, or tobacco at least two hours before the test. Pressure measurements were taken in the upper and LLs (Figure 2) and were used to calculate the $A B I s .{ }^{14}$ The $A B I$ values were interpreted according to the classification suggested by Aboyans et al., ${ }^{14}$ where values $\leq 0.90$ indicate a high cardiovascular risk; values between 0.91 and 1.00 indicate a borderline risk; and values between 1.10 and 1.39 are considered normal. 


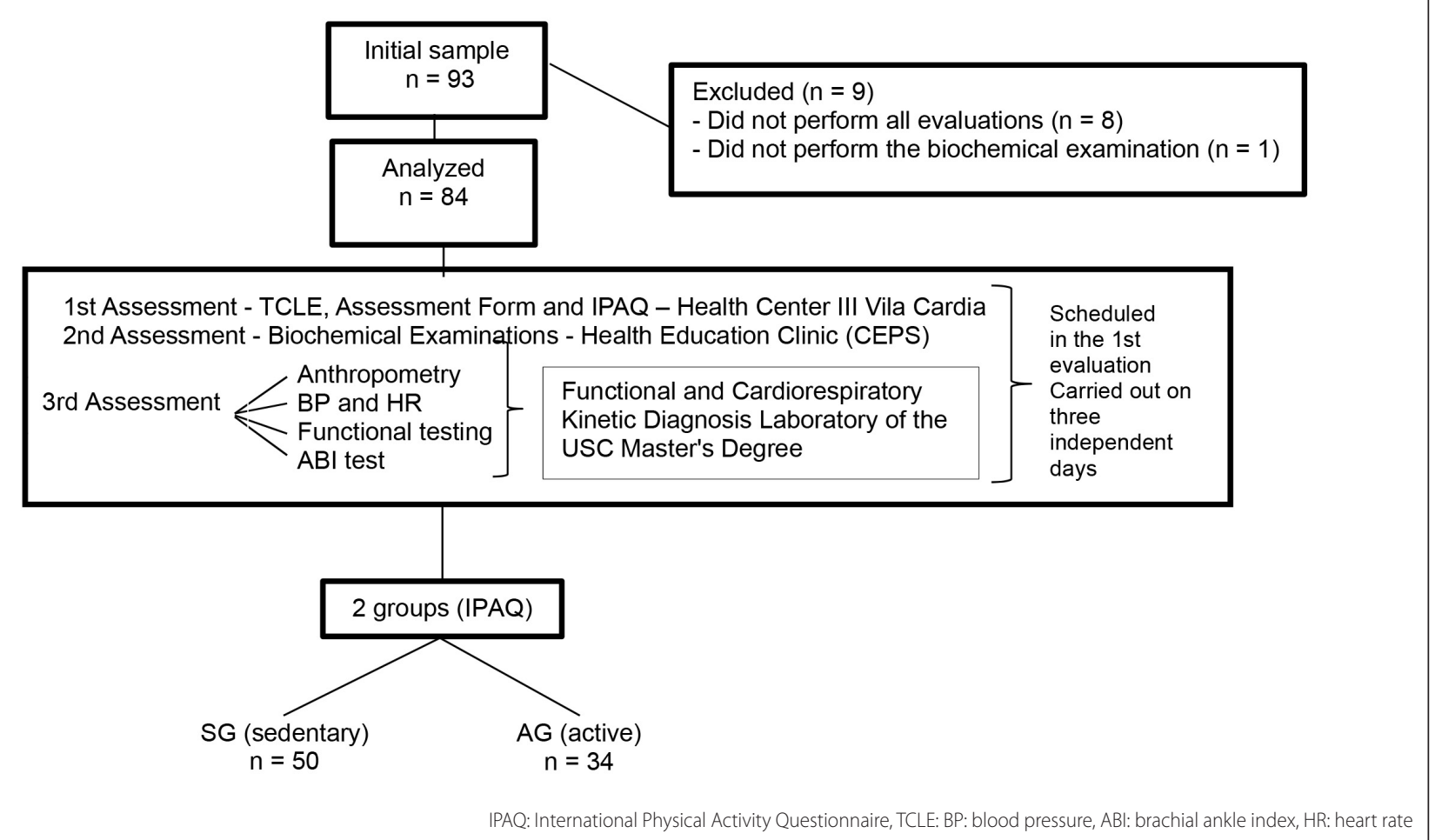

Figure 1. Study design and follow-up of volunteers.

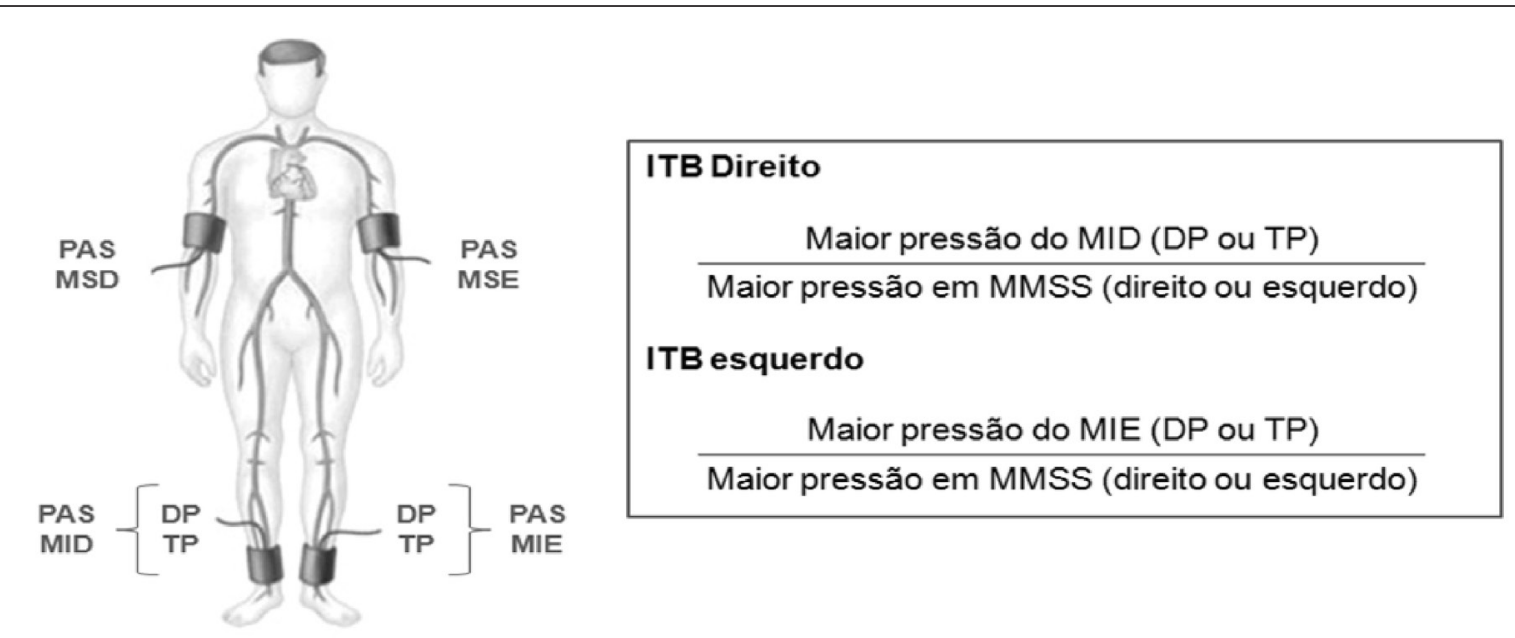

Source: adapted from Copyright @ 2016 Ecography Laboratório Vascular. SBP: systolic blood pressure, RUL: right upper limb, LUL: left upper limb, RLL: right lower limb, LLL: left lower limb, DPA: dorsalis pedis artery, PTA: posterior tibial artery, ABI: brachial ankle index.

Figure 2. ABI measurement sites using a portable vascular Doppler.

For BP measurements, the individuals remained at rest in a calm environment for five minutes, in a dorsal decubitus position. Measurements were taken in the following order: right upper limb, right $L L$, left $L L$, left upper limb and again in the right upper limb. The arterial pressure measurements of the LLs were similar to that of the brachial arterial pressure, but with the cuff placed around the ankle, with the lower edge of the cuff positioned at least two centimeters above the medial malleolus. A gel was used to allow contact of the Doppler transducer to the skin. The transducer was placed in the pulse zone of the posterior tibial artery or the dorsalis pedis artery, with a $45^{\circ}$ to $60^{\circ}$ angle in relation to the skin, and moved until the strongest signal was heard. The cuff was progressively inflated up to $20 \mathrm{mmHg}$ above the level of disappearance of the Doppler signal and then was slowly deflated.
The Short Physical Performance Battery (SPPB) and the six-minute walk test (6-MWT) were used to evaluate the functional performance of the LLs. The SPPB is composed of three tests that evaluate the static standing balance, the gait speed in steps, and the muscle strength of the LLS, and was adapted to the Portuguese language by Nakano. ${ }^{15}$ The total SPPB score was determined by the sum of the scores of the three tests, ranging from zero (worst performance) to 12 points (best performance).

Balance tests: individuals remained in each position (side-by-side, semi-tandem stand, and tandem stand) for 10 seconds. The score was defined as: zero for the elderly unable to maintain balance in the first position for 10 seconds; one point if he/she was able to remain in the first position for 10 seconds; two points if he/she was able to remain in the second position for 10 seconds and could not remain in the third position for more than three seconds; three points if he/she remained in the third 
position for three to nine seconds; and the maximum score of four points for those who managed to remain in the third position for 10 seconds.

Walking speed test: individuals travelled a predetermined distance of four meters with the score defined as: zero if they were unable to complete the test; one point for a time equal to or less than 8.70 seconds; two points for a time between 6.21 and 8.70 seconds; three points for a time between 4.82 and 6.20 seconds; and a maximum score of four points for times less than 4.82 seconds.

Muscle strength test of the LLs: individuals sat down and got up from the chair 5 consecutive times without any help from their upper limbs. The scores were: zero if the test was not completed; one point when the time was greater than 16.7 seconds; two points for times between 13.7 and 16.6 seconds; three points for times from 11.2 to 13.6 seconds; and a maximum of four points for times less than 11.1 seconds.

The 6-MWT was based on the norms established by the American Thoracic Society. ${ }^{16}$ The evaluator guided the individuals by means of standardized phrases to travel the longest possible distance as fast as possible in 6 minutes on a flat, 30 meter straight corridor. The starting point and the end of the course were marked with cones and the floor was marked with adhesive tape. Individuals were instructed to discontinue the test if they felt tired, dizzy, or suffered other symptoms of discomfort. At the end of the 6 minutes, the total distance traveled was recorded in meters. BP was measured before and after the evaluation of the test and HR measurements were taken before, during, and at the end of the test.

Statistical analyses were performed using BioEstat 5.3 and SPSS (Statistical Package for the Social Sciences) 20.0 software programs. The normality of the data was verified by the Shapiro-Wilk test and the data were expressed as means ( \pm standard deviations) or medians (interquartile ranges) for the variables with normal and non-normal distributions, respectively. The Student's t-test and the Mann-Whitney test were used to compare the groups. Fisher's exact test was used to analyze categorical data. A level of $p<0.05$ was considered statistically significant.

\section{RESULTS}

The clinical, anthropometric, and hemodynamic characteristics of the SG and $A G$ groups are presented in Table 1. When compared to the SG, the AG had a lower number of individuals with arterial hypertension $(p=0.029)$ and lower values of body mass $(p=0.011)$, BMI $(p=0.041)$, and AC ( $p=0.029)$.

Table 1. Clinical, anthropometric, hemodynamic, and biochemical characteristics of the sedentary (SG) and active (AG) groups.

\begin{tabular}{c|c|c|c}
\hline Variables & SG $(\mathbf{n}=\mathbf{5 0})$ & AG $(\mathbf{n}=\mathbf{3 4})$ & p-value \\
\hline Age (years) & $69(7.7)$ & $70(7.7)$ & 0.438 \\
\hline Sex (M/F), $\mathrm{n}(\%)$ & $12(24) / 38(76)$ & $6(17.6) / 28(81.4)$ & 0.338 \\
\hline Coronary heart disease, $\mathrm{n}(\%)$ & $6(12)$ & $6(18)$ & 0.337 \\
\hline Hypertension, $\mathrm{n}(\%)$ & $35(70)$ & $16(47)$ & $0.029^{*}$ \\
\hline Diabetes, $\mathrm{n}(\%)$ & $18(36)$ & $10(29)$ & 0.349 \\
\hline Hypothyroidism, $\mathrm{n}(\%)$ & $9(18)$ & $8(23)$ & 0.362 \\
\hline Smoker, $\mathrm{n}(\%)$ & $2(4)$ & $3(9)$ & 0.202 \\
\hline Alcoholic drink, $\mathrm{n}(\%)$ & $14(28)$ & $16(47)$ & 0.060 \\
\hline Anthropometric & & & \\
\hline Body weight $(\mathrm{kg})$ & $67.8(15.1)$ & $65.1(13.6)$ & $0.011^{*}$ \\
\hline BMI $\left(\mathrm{kg} / \mathrm{m}^{2}\right)$ & $27.9 \pm 4.6$ & $26.2 \pm 3.9$ & $0.041^{*}$ \\
\hline AC $(\mathrm{cm})$ & $99.1 \pm 11.8$ & $94.53 \pm 3.0$ & $0.029^{*}$ \\
\hline Hemodynamic & & & \\
\hline SBP $(\mathrm{mmHg})$ & $123(29.0)$ & $129(28.0)$ & 0.463 \\
\hline DBP (mmHg) & $70(13.5)$ & $70(9.0)$ & 0.978 \\
\hline HR (bpm) & $71(17.5)$ & $70(13.7)$ & 0.452 \\
\hline
\end{tabular}

Values expressed in absolute and relative frequency (\%) mean \pm standard deviation, or median (interquartile

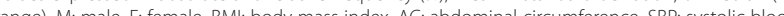
range). M: male, F: female, BMI: body mass index, AC: abdominal circumference, SBP: systolic blood pressure DBP: diastolic blood pressure, HR: heart rate. P-values based on Student's t-test, Mann Whitney's test and Fisher's exact test. ${ }^{*}$ Significant result $(\mathrm{p}<0.05)$
The results related to lipid profiles, $A B \mid s$, and functional performances are presented in Table 2. The AG had significantly higher values of HDL-C and lower values of TG compared to the SG. There was no significant difference between the groups for total cholesterol and LDL-c. (Table 2)

The SG had lower right, left, and final ABls in relation to the AG, indicating greater involvement in the SG. There were better results in the functional performances of the AG in the SPPB evaluation and with greater distances traveled on the 6-MWT compared to the SG.

In the analysis of the variables that make up the SPPB, the AG had better performances in the equilibrium test in the tandem stand position. In the LL muscle strength test, $77 \%$ of the AG had a better performance with times $<11.1$ seconds in relation to the SG (Table 3 ).

Medication use: $39 \%$ of the total group used antihypertensive agents; 19\% used medications for neurological diseases; $10 \%$ for cardiovascular diseases; $8 \%$ for diabetes; $7 \%$ used antidyslipidemic drugs; $6 \%$ for arthrosis; $3 \%$ for osteoporosis, pulmonary diseases and hypothyroidism; and $1 \%$ for protection of the gastric mucosa and dermatological diseases.

Table 2. Comparison lipid profiles, ankle-brachial indices (ABI), and functional performances of the elderly.

\begin{tabular}{c|c|c|c}
\hline Biochemical & SG $(\mathbf{n}=\mathbf{5 0})$ & AG $(\mathbf{n}=\mathbf{3 4})$ & p-value \\
\hline Total cholesterol $(\mathrm{mg} / \mathrm{dl})$ & $192.4 \pm 40.4$ & $197.8 \pm 41.6$ & 0.279 \\
\hline HDL-c $(\mathrm{mg} / \mathrm{dl})$ & $48.1(13,6)$ & $55.8(12.6)$ & $0.001^{*}$ \\
\hline LDL-c $(\mathrm{mg} / \mathrm{dl})$ & $112.6 \pm 34.7$ & $118.2 \pm 40.2$ & 0.249 \\
\hline TG $(\mathrm{mg} / \mathrm{dl})$ & $150.3(88.3)$ & $111.9(55.6)$ & $0.007^{*}$ \\
\hline ABI Measure & & & \\
\hline Right ABI & $1,090 \pm 0.131$ & $1,145 \pm 0.089$ & $0.012^{*}$ \\
\hline Left ABI & $1,086(0.184)$ & $1,118(0.133)$ & $0.015^{*}$ \\
\hline Final ABI & $1,040(0.164)$ & $1,115(0.110)$ & $0.004^{*}$ \\
\hline Functional evaluation & & & \\
\hline SPPB (scale 0-12) & $11.0(2.7)$ & $12.0(1.0)$ & $0.0007^{*}$ \\
\hline 6-MWT (m) & $470.6 \pm 93.2$ & $519.2 \pm 62.7$ & $0.0027^{*}$ \\
\hline
\end{tabular}

Values expressed as mean \pm standard deviation and median (interquartile range). SG: sedentary group AG: active group, HDL-c: high-density lipoprotein, LDL-c: low-density lipoprotein; TG: triglyceride, ABl: ankle-brachial index SPPB: Short Physical Performance Battery, 6-MWT: six-minute walk test. Student t and Mann Whitney tests: * $p<0.05$

Table 3. Comparison of the SPPB variables of the elderly.

\begin{tabular}{|c|c|c|c|c|}
\hline Test & SPPB variables & $S G(n=50)$ & $A G(n=34)$ & p-value \\
\hline \multirow{10}{*}{ Balance } & Side by side & & & \\
\hline & Maintained for $10 \mathrm{~s}$ & $50(100)$ & $34(100)$ & 1.000 \\
\hline & Did not maintain for $10 \mathrm{~s}$ & 0.0 & 0.0 & 1.000 \\
\hline & Semi-tandem stand & & & \\
\hline & Maintained for $10 \mathrm{~s}$ & $48(96)$ & $34(100)$ & 0.351 \\
\hline & Did not maintain for $10 \mathrm{~s}$ & $2(4)$ & $0(0)$ & 0.351 \\
\hline & Tandem stand & & & \\
\hline & Maintained up to $3 \mathrm{~s}$ & $6(12)$ & $1(3)$ & 0.141 \\
\hline & Maintained from 3 to $9.9 \mathrm{~s}$ & $5(10)$ & $1(3)$ & 0.216 \\
\hline & Maintained for $10 \mathrm{~s}$ & $39(78)$ & $32(94)$ & 0.040 \\
\hline \multirow{3}{*}{$\begin{array}{l}\text { Walking } \\
\text { speed }\end{array}$} & Between 6.21 and $8.70 \mathrm{~s}$ & $3(6)$ & $0(0)$ & 0.205 \\
\hline & Between 4.82 and $6.20 \mathrm{~s}$ & $16(32)$ & $7(21)$ & 0.184 \\
\hline & $<4.82 \mathrm{~s}$ & $31(62)$ & $27(79)$ & 0.071 \\
\hline \multirow{5}{*}{$\begin{array}{c}\text { Muscle } \\
\text { strength of the } \\
\text { lower limbs }\end{array}$} & Did not complete & $3(6)$ & $1(3)$ & 0.464 \\
\hline & $>16.7 \mathrm{~s}$ & $3(6)$ & 0,0 & 0.205 \\
\hline & Between 13.7 and $16.6 \mathrm{~s}$ & $6(12)$ & 0,0 & 0.039 \\
\hline & Between 11.2 and $13.6 \mathrm{~s}$ & $18(36)$ & $7(21)$ & 0.100 \\
\hline & $<11.1 \mathrm{~s}$ & $20(40)$ & $26(77)$ & 0.001 \\
\hline
\end{tabular}

SPPB: Short Physical Performance Battery, SG: sedentary group, AG: active group (absolute and relative frequenc values). Fisher's exact test $(p<0.05)$ 


\section{DISCUSSION}

This study aimed at determining whether active elderly individuals have a better lipid profile, functional capacity, and ankle-brachial index when compared to sedentary elderly individuals.

Significant differences were identified, with the SG having greater AC values. Garcez et al. ${ }^{17}$ observed in a cross-sectional population-based study that elderly individuals with inadequate ACs had a higher prevalence of low levels of HDL-c. The same was observed in the present study where the SG had lower levels of HDL-c and higher levels of TG compared to the AG. These data corroborate the findings in the study by Ferreira et al., ${ }^{2}$ who found a moderate positive correlation between the level of physical activity and HDLs and found higher levels of TG in the sedentary elderly.

No significant differences in TC and LDL-c were observed between the groups studied, although both had desirable lipid levels, according to the V Brazilian Directive on Dyslipidemias and Prevention of Atherosclerosis. ${ }^{5}$ Nevertheless, it should be considered that these variables are subject to change when physical exercise is used. This was observed in a study by Angel et al., ${ }^{18}$ who used physical exercise and showed changes in the lipid profiles, reduction and redistribution of body fat, and increased enzymes that regulate lipoprotein metabolism. In a study by Anjo et al., ${ }_{1}^{18}$ the researchers found that after 12 weeks of physical exercise (aerobic and muscle strength), there was a decrease in $\mathrm{TG}$, an increase in $\mathrm{HDL}-\mathrm{C}$, and a decrease in TC and LDL-C. According to the American College of Sports Medicine ${ }^{19}$, physical activity and physical exercise have different meanings: physical exercise is systematized, planned, and structured, while physical activity encompasses any movement that results in energy expenditure. It is worth mentioning that this study used the level of physical activity based on the IPAQ.

In the present study, the BIT values in the SG were considered "Limit", which demonstrates a higher probability of developing atherosclerosis and CVD compared to the AG, which had "Normal" values. ${ }^{14}$

In the study by Ruiz Comellas et al. ${ }^{20}$ with 2,840 individuals, a positive relationship between free-time physical activity in metabolic equivalents and ABls was observed. The same was demonstrated by Heikkilä et al., ${ }^{21}$ who followed 123 individuals for seven years and who were treated for multiple risk factors for CVD. The authors concluded that those who performed physical activities in their free time had improved $A B I$ values.
Regular physical activity helps vascular adaptation, improves blood flow in the LLs, and contributes to reducing the risk of developing atherosclerosis and CVD.22

Torres et al. ${ }^{6}$ emphasized the importance of using ABIs in individuals $\geq 55$ years of age to identify early blood flow restrictions and enable interventions in risk factors for CVD to minimize its complications.

Regarding functional capacity, the present study showed that the AG scored better in the SPPB test than the SG, especially with the balance and muscle strength performances of their LLs. The AG also covered greater distances in the 6-MWT. For Gonzaga et al., ${ }^{23}$ who evaluated the levels of physical activity, functional capacity, and gaits of the elderly, the groups that practiced regular physical activity had better functional fitness than the control group. Cordeiro et al., ${ }^{24}$ in the evaluation of quality of life (SF-36), also observed that the active elderly had significantly higher functional levels than the insufficiently active elderly, which reinforced the premise that regular physical activity provided improvement in functional capacity, even during the aging process.

The practice of regular physical activity favors healthy aging, reduces the inherent losses of functional capacity, prevents CVD, and improves the quality of life of the elderly. ${ }^{25,26}$

Another aspect highlighted in the present study is arterial hypertension, which was higher in the SG than in the AG. Individuals with cardiometabolic abnormalities, such as hypertension, are more likely to be less physically active. ${ }^{27}$ Hypertension is a multifactorial disease in which morbidity and prevalence are associated with sedentary lifestyles. ${ }^{28}$ Physical activity contributes to the control of BP and reduces the incidence of hypertension and the risk of CVD. ${ }^{29,30}$

\section{CONCLUSION}

Based on the results presented herein, it is possible to conclude that in comparison with sedentary elderly individuals, active individuals had better lipid profiles, higher levels of ABIs, and better functional performances in addition to lower anthropometric measurements (BMl and AC) and lower incidences of hypertension.

All authors declare no potential conflict of interest related to this article

AUTHORS' CONTRIBUTIONS: Each author made significant individual contributions to this manuscript. TSM (0000-0002-6367-0672)*: contributed to the conception and design of the work, scheduling of appointments with the research subjects, data collection, statistical analysis, data interpretation, intellectual concept of the article, creation of the entire research project, writing and critical review of the content; $\mathrm{ADH}(0000-0002-0681-3972)^{*}$ : contributed to the conception and design of the work, data collection, critical review of the intellectual content; CG (0000-0002-1092-1896)*, EAA (0000-0003-1795-3089)*, BVPS (0000-0002-6806-6239)*, BM (0000-0002-8326-0419)* and ARZ (0000-0002-7480-3047)*: critical review of the intellectual content; SRB (0000-0001-6091-9287)*: contributed to the conception and design of the work, statistical analysis, data interpretation, intellectual concept of the article, creation of the entire research project, writing and critical review of its intellectual content. All are in agreement with, and accept responsibility for, all the aspects of the work as concerns matters related to data integrity or accuracy. All authors approved the final version of the manuscript. *ORCID (Open Researcher and Contributor ID).

\section{REFERENCES}

1. Karuka AH, Silva JA, Navega MT. Análise da concordância entre instrumentos de avaliação do equilíbrio corporal em idosos. Rev Bras Fisioter. 2011;15(6):460-6.

2. Ferreira AP, Picolli T, Bordin A, Rech A, Poeta J, Tiggemann CL, et al. Baixos níveis de atividade física estão associados a prejuízos no perfil lipídico e aumento do percentual de gordura de indivíduos idosos. Rev Bras Cien Mov. 2015;23(3):135-42.

3. Gomes Neto M, Castro MF. Estudo comparativo da independência funcional e qualidade de vida entre idosos ativos e sedentários. Rev Bras Med Esporte. 2012; 18(4): 234-7.

4. Moraes SA, Checchio MV, Freitas IC. Dislipidemia e fatores associados em adultos residentes em Ribeirão Preto, SP: resultados do Projeto EPIDCV. Arq Bras Endocrinol Metabol. 2013;57(9):691-701.

5. Xavier HT, Izar MC, Faria Neto JR, Assad MH, Rocha VZ, Sposito AC, et al.V Diretriz Brasileira de Dislipidemias e Prevenção da Aterosclerose. Arq Bras Cardiol. 2013; 101 (4 Suppl 1):1-20.

6. Torres AG, Machado EG, Lopes TS, Gentile PC, Vieira AC, Soares LG, et al. Prevalência de alterações do índice tornozelo-braço em indivíduos portadores assintomáticos de doença arterial obstrutiva periférica. Rev Bras Cardiol. 2012;25(2):87-93.

7. Forés R, Alzamora MT, Pera G,Tóran $\mathrm{P}, \mathrm{U}$ rrea M, Heras A. Concordancia entre 3 métodos de medición del índice tobillo-brazo para el diagnóstico de arteriopatía periférica. Med Clin (Barc). 2014;143(8):335-40

8. Matsudo S, Araujo T, Matsudo V, Andrade D, Andrade E, Oliveira LC, et al. Questinário internacional de atividade física (IPAQ): estudo de validade e reprodutibilidade no Brasil. Rev Bras Ativ Fis Saude. 2001;6(2):05-18.

9. de Lima DF, Levy RB, Luiz OC. Recomendações para atividade física e saúde: consensos, controvérsias e ambiguidades. Rev Panam Salud Publica. 2014;36(3):164-70.

10. Friedewald WT, Levy RI, Fredrickson DS. Estimation of the concentration of low-density lipoprotein cholesterol in plasma, without use of the preparative ultracentrifuge. Clin Chem. 1972;18(6):499-502.

11. Keys A, Fidanza F, Karvonen MJ, Kimura N, Taylor HL. Indices of relative weight and obesity. Int J Epidemiol. 2014;43(3):655-65.

12. Nagatsuyu DT, Moriguti EK, Pfrimer K, Formighieri PF, Lima NK, Ferriolli E, et al. O impacto da obesidade abdominal sobre os níveis plasmáticos de lipídeos nos idosos. Medicina (Ribeirão Preto). 2009;42(2):157-63.

13. Malachias MV, Souza WK, Plavnik FL, Rodrigues Cl, Brandão AA, Neves MF, et al. 7a Diretriz Brasileira de Hipertensão Arterial. Arq Bras Cardiol. 2016 [acesso em 2016, out, 28] ;107(3 Suppl 3):1-83. Disponível em: http://www.scielo.br/pdf/abc/v107n3s3/0066-782X-abc-107-03-s3-0049.pdf 
14. Aboyans V, Criqui MH, Abraham P, Allison MA, Creager MA, Diehm C, et al. Measurement and interpretation of the ankle-brachial index: a scientific statement from the American Heart Association. Circulation. 2012:126(24): 2890-909.

15. Nakano MM. Versão Brasileira da Short Physical Performance Battery - SPPB: adaptação cultural e estudo da confiabilidade. 163 f. Dissertação (Mestrado em Gerontologia) - Universidade Estadual de Campinas, Campinas, SP, 2007. [acesso em 2015, maio, 20].Disponível em: http://www.bibliotecadigital.unicamp. $\mathrm{br} /$ document/?code $=\mathrm{vt} \mid \mathrm{s} 000412296$

16. ATS Committee on Proficiency Standards for Clinical Pulmonary Function Laboratories. ATS statement: guidelines for the six-minute walk test. Am J Respir Crit Care Med. 2002;166(1):111-7.

17. Garcez MR, Pereira JL, Fontanelli Mde M, Marchioni DM, Fisberg RM. Prevalência de dislipidemia segundo estado nutricional em amostra representativa de São Paulo. Arq Bras Cardiol. 2014;103(6):476-84

18. Anjo D, Santos M, Rodrigues P, Brochado B, Sousa MJ, Barreira A, et al. Os benefícios da reabilitação cardíaca na doença coronária: uma questão de gênero? Rev Port Cardiol. 2014;33(2):79-87.

19. Garber CE, Blissmer B, Deschenes MR, Franklin BA, Lamonte MJ, Lee IM, et al. American College of Sports Medicine position stand. Quantity and quality of exercise for developing and maintaining cardiorespiratory, musculoskeletal, and neuromotor fitness in apparently healthy adults: guidance for prescribing exercise. Med Sci Sports Exerc. 2011;43(7):1334-59

20. Ruiz Comellas A, Pera G, Baena Díez JM, Heras A, Alzamora Sas MT, Forés Raurell R, et al. The relationship between physical activity in leasure time and the ankle-brachial index in a general Spanish population: The ARTPER study. Med Clin (Barc). 2015;145(10):419-26.

21. Heikkilä A, Venermo M, Kautiainen H, Aarnio P, Korhonem P. Physical Activity Improves Borderline Ankle-Brachial Index Values in a Cardiovascular Risk Population. Ann Vasc Surg. 2016;32:50-6.

22. Limberg JK, Johansson RS, McBride PE, Schrage WG. Increased leg blood flow and improved femoral artery shear patterns in metabolic syndrome after a diet and exercise programme. Clin Physiol Funct Imaging. 2014;34(4):282-9.

23. Gonzaga JM, Barros SE, Lisboa MG, Barbieri FA, Gobbi LT. Efeitos de diferentes tipos de exercício nos parâmetros do andar de idosas. Rev Bras Med Esporte. 2011;17(3):166-70.

24. Cordeiro J, Del Castillo BL, de Freitas CS, Gonçalves MP. Efeitos da atividade física na memória declarativa, capacidade funcional e qualidade de vida em idosos. Rev Bras Geriatr Gerontol. 2014;17(3):541-52

25. Campos AC, Almeida MH, Campos GV, Bogutchi TF. Prevalência de incapacidade funcional por gênero em idosos brasileiros: uma revisão sistemática com metanálise. Rev Bras Geriatr Gerontol. 2016;19(3):545-59.

26. Burton NW, Ademi Z, Best S, Singh MA, Jenkins JS, Lawson KD, et al. Efficacy of brief behavioral counselling by allied health professionals to promote physical activity in people with peripheral arterial disease (BIPP): study protocol for a multi-center randomized controlled trial. BMC Public Health. 2016;16(1):1148.

27. Freitas C, Deschênes S, Au B, Smith K, Schmitz N. Risk of Diabetes in older adults with cooccurring depressive symptoms and cardiometabolic abnormalities: prospective analysis from the Eenglish longitudinal study of ageing. PloS One. 2016; 11(5):e0155741.

28. Carvalho CJ, Marins JC, Amorim PR, Fernandes MF, Reis HH, Sales SS, et al. Altas taxas de sedentarismo e fatores de risco cardiovascular em pacientes com hipertensão arterial resistente. Medicina (Ribeirão Preto). 2016;49(2):124-33.

29. Souza CS, Stein AT, Bastos GA, Pellanda LC. Controle da pressão arterial em hipertensos do Programa Hiperdia: estudo de base territorial. Arq Bras Cardiol. 2014;102(6):571-8.

30. Pimenta HB, Caldeira AP. Fatores de risco cardiovascular do escore de Framingham entre hipertensos assistidos por equipes de saúde da família. Ciên Saude Colet. 2014; 19(6):1731-39. 